\title{
A Study of a Causality Relationship between Firm Investment and Cash Holdings: An Empirical Validation from French, Germany and Italy
}

\author{
Ben Said Hatem (Corresponding author) \\ Faculty of Law, Economics and Management of Jendouba \\ University of Jendouba, Jendouba, Tunisia \\ E-mail: hatmbensaid@gmail.com
}

Received: July 14, 2016 Accepted: May 5, 2017

doi:10.5296/ber.v7i1.9737 URL: https://doi.org/10.5296/ber.v7i1.9737

\begin{abstract}
This paper tests the causality interdependence between firm investment and cash holdings. Our study analyzes three countries: French, Germany and Italy. The samples contain 84 firms for each country over a period of 8 years from 2003 to 2010. Cash is measured, alternatively by two ratios; cash and cash equivalents over total assets, and quick ratio approximated by cash and cash equivalents over current liabilities. Firm investment is approximated by tangible fixed assets growth rate and total assets growth rate. As control variables: profitability, leverage, size and firm age. Using a data panels method, the causality relationship is not checked for all countries. However, for French and Italy markets, we conclude to a causality relationship for the service and agriculture and mining sectors, respectively.
\end{abstract}

Keywords: Firm investment, Cash holdings, Causality, Profitability, Growth rate

\section{Introduction}

Is there a causality relationship between cash holdings and firm investment? (Acharya et al., 2007; Almeida et al., 2004; Bates et al., 2009). Brown and Petersen (2011) argue that most of firms spend cash in investment. Denis and Sibilkov (2010) found a significant relationship between cash and investment. Mikkelson and Partch (2003) show that cash holdings is strongly explained by firm investment (research and development expenses) and growth rate of total assets. Myers and Majluf, 1984 suggest that external funds are costly because of agency problems. Harford (1999) suggest that acquisition can be explained by cash holdings. Kim et al. (1998) study the relation between cash and investment decision. They conclude to 
a positive and a statistically significant relationship between investment decision and cash flow volatility. Minton and Schrand (1999) found a contradictory result. Thus, there is a interdependence between firm investment and cash holdings. The aim of this paper then is to test the causality interdependence between cash holdings and firm investment. The next section will review the other papers that examined the relationship between investment and cash. In Section 3, we introduce our sample, the tested models and our variables. Section 4 presents the descriptive statistics and our empirical results. A sensitivity analysis of our results by industries is made in section 5 . The last section manipulates our findings.

\section{The Literature Review}

Like Leland (1968), Dreze and Modigliani(1972) and Caballero (1990), Seungjin, Jiaping (2007) argue that firms hold cash for some reasons. Using a sample of public companies in the United States market for a period of 6 years from 1997 to 2002, the authors do not conclude to a significant relationship between cash holdings and cash flows volatility.

Similar to Abadie and Imbens (2006) and Çolak and Whited (2007), Eric, Gönül and David (2013) analysed the determinants of corporate cash holdings. Indeed, the authors examined the change in cash before and after introduction of the firms in the stock market. Using a sample of 775 firms for a period of 36 years from 1971 to 2006, the authors conclude to a decreased cash of about $32 \%$ after the introduction of about one year. Agency problems within these firms become severe, which implies a reduction of liquidity. This result is supported by free cash flows hypothesis. Furthermore, the authors found a negative and a statistically significant interdependence between investment and cash holdings.

Like Myers and Majluf (1984), and Goergen Renneboog (2001), Wei and Zhang (2008), and Andres (2011), Thomas Connelly (2016) highlights the determinants of investment decision for family firms. The authors use as a measure of investment decision two ratios. The authors test the following explanatory factors; growth opportunities, ownership structure, profitability and leverage. Examining a sample of public firms from Thailand, they highight a positive and a statistically significant effect of ownership structure on debt ratios. However, family ownership can affect this relationship. The results also highlight a positive and a statistically significant modification of growth opportunities on leverage. However, the effect of this variable for family firms is not statistically significant. Furthermore, the effect of size, profitability and capital structure is positive and statistically significant.

\section{Data and Methodology}

\subsection{Sample Selection}

To study of a causality relationship between investment decision and the firm cash holdings policy, we use of the following data extracted from the « Amadeus » database. 84 companies for each of the following countries: French, Germany and Italy for a period of 8 years from 2003 to 2010. 


\subsection{Introduction of Variables and Hypothesis}

The dependent variable

Firm investment: according to the works of Hoshi et al. (1991) and Almeida et al.(2004), we use two alternatives to measure firm investment: growth rates of tangible fixed assets and growth rate of total assets. Generally, more investment projects means less of cash. However, profitable investment projects result in gains, and therefore more cash. Hypothesis 1: Firm investment can positively or negatively affect cash holdings.

Cash holdings: following the works of Ranjan, Krishnaswami and Larkin (2008), Acharya et al (2013) and Nuno and Gonenc (2016), in this study we measure firm cash as follows:

- The first variable measures the cash held by the firm using the following ratio: cash and equivalents of cash to total assets.

- The second variable holds the following ratio: cash and equivalents of cash to current liabilities.

The more the firm has cash, the more it will be able to undertake investment projects at lower cost. Hypothesis 2: cash holdings positively affects investment.

The independent variables

Profitability: according to works of Jarrad, Sattar, and William (2008), we measure firm profitability by the ratio of earnings before interests and taxes over total assets. Generally, a high value of firm profitability does not stimulate managers to make new investment projects. Hypothesis 3a: profitability negatively affects firm investment. However, if the operating activity generates higher earnings, it means that the company holds more cash. Hypothesis $\mathbf{3} \boldsymbol{b}$ : firm profitability positively affects firm cash holdings.

Leverage: similarly to the works of Opler, Pinkowitz, Stulz, and Williamson (1999), we estimate leverage as the ratio of long-term debt to total assets. High levels of debt ratios mean much money in the hands of managers. This cash excess may cause conflicts of interest between managers and shareholders. In this case, the owners will try to use this debt to finance the operating activity and implement new investment projects. Hypothesis 4a: The debt ratio affects positively or negatively firm investment. The study of the interdependence between leverage and cash may cause two trends: according to John (1993) higher debts ratios leads to less cash. However, Hovakimian and Titman (2003) and Fazzari et al. (1988) argue that high debt levels may increase bankruptcy risk of the firm. To minimize this risk, the managers will try to hold more cash. Hypothesis $\mathbf{4 b}$ : the leverage positively or negatively affects cash holdings.

Firm size: according to the works of Jarrad, Sattar, and William (2008), we measure firm size as the logarithm of total assets. Stuart (2000) and Aldrich and Auster (1986) suggest that large firms are more recognized and are more efficient. In this case, large firms can obtain funding sources at the lowest cost to finance their investment projects (Dittmar et al., 2003). Hypothesis 5a: The firm size positively affects firm investment. Titman and Wessels 1988 


\section{Macrothink}

suggest that the higher the firm size, the lower bankruptcy risk. However, Whited, (1992) and Fazzari and Petersen (1993) suggest that financing cost for small firms is higher than others. These arguments lead us to suggest a negative interdependence between firm size and cash. Hypothesis $\mathbf{5} \boldsymbol{b}$. firm size negatively affects cash holdings.

Firm age: Similarly to William, Richard and Scott (2015), we measure firm age by the logarithm of the number of years between the present date and incorporation date. The older firms are more recognized and have generally of larger size. Hypothesis 6a: firm age negatively explains firm investment. On the other hand, the older firms can obtain financing funds at lower costs. Hypothesis $\boldsymbol{6} \boldsymbol{b}$ : firm age positively affects cash holdings.

Table 1. Variables and expected signs

\begin{tabular}{|l|c|l|c|}
\hline Variables & Abbreviation & Formulation & Expected sign \\
\hline Firm investment & INVTANG & Growth rate of tangible fixed assets & Dependant Variable (+/-) \\
\hline Firm investment & INVTA & Growth rate of total assets & Dependant Variable $(+/-)$ \\
\hline Cash holdings & CASH & Cash and Cash equivalents / TA & Dependant Variable $(+)$ \\
\hline Cash holdings & QR & $\begin{array}{l}\text { Cash and Cash } \\
\text { equivalents / current liabilities }\end{array}$ & Dependant Variable $(+)$ \\
\hline Profitability & PROF & EBITDA / TA & $(-/+)$ \\
\hline Leverage & DR & LTD / TA & $(+/-)$ \\
\hline SIZE & SIZE & Ln (TA) & $(+/-)$ \\
\hline Firm age & Age & Ln ( Firm age) & $(-/+)$ \\
\hline $\begin{array}{l}\text { TA: total assets. EBITDA : Earnings Before Interests, Taxes and Depreciation. LTD: long term debt. } \\
\text { Firm age: number of years between current date and date of incorporation. }\end{array}$
\end{tabular}

\subsection{The Tested Models}

To test the causality relationship between firm investment and cash holdings (Denis and Sibilkov, 2010; Duchin et al., 2010; Harford et al., 2014)

$$
\begin{aligned}
& I N V T A N G_{i t}=\alpha_{0}^{1}+\alpha_{1}^{1} * C_{A S H}+\alpha_{2}^{1} * P R O F_{i t}+\alpha_{3}^{1} * D R_{i t}+\alpha_{4}^{1} * S I Z E_{i t}+\alpha_{5}^{1} * A G E_{i t}+\varepsilon_{i t}^{1} \\
& I N V T A N G_{i t}=\alpha_{0}^{2}+\alpha_{1}^{2} * Q R_{i t}+\alpha_{2}^{2} * P R O F_{i t}+\alpha_{3}^{2} * D R_{i t}+\alpha_{4}^{2} * S I Z E_{i t}+\alpha_{5}^{2} * A G E_{i t}+\varepsilon_{i t}^{2} \\
& I N V T A_{i t}=\alpha_{0}^{3}+\alpha_{1}^{3} * C A S H_{i t}+\alpha_{2}^{3} * P R O F_{i t}+\alpha_{3}^{3} * D R_{i t}+\alpha_{4}^{3} * S I Z E_{i t}+\alpha_{5}^{3} * A G E_{i t}+\varepsilon_{i t}^{3} \\
& I N V T A_{i t}=\alpha_{0}^{4}+\alpha_{1}^{4} * Q R_{i t}+\alpha_{2}^{4} * P R O F_{i t}+\alpha_{3}^{4} * D R_{i t}+\alpha_{4}^{4} * S I Z E_{i t}+\alpha_{5}^{4} * A G E_{i t}+\varepsilon_{i t}^{4} \\
& \text { CASH }_{i t}=\alpha_{0}^{5}+\alpha_{1}^{5} * I N V T A N G_{i t}+\alpha_{2}^{5} * P R O F_{i t}+\alpha_{3}^{5} * D R_{i t}+\alpha_{4}^{5} * S I Z E_{i t}+\alpha_{5}^{5} * A G E_{i t}+\varepsilon_{i t}^{5} \\
& \operatorname{CASH}_{i t}=\alpha_{0}^{6}+\alpha_{1}^{5} * I N V T A_{i t}+\alpha_{2}^{6} * P R O F_{i t}+\alpha_{3}^{6} * D R_{i t}+\alpha_{4}^{6} * S I Z E_{i t}+\alpha_{5}^{6} * A G E_{i t}+\varepsilon_{i t}^{6} \\
& Q R_{i t}=\alpha_{0}^{7}+\alpha_{1}^{7} * I N V T A N G_{i t}+\alpha_{2}^{7} * P R O F_{i t}+\alpha_{3}^{7} * D R_{i t}+\alpha_{4}^{7} * S I Z E_{i t}+\alpha_{5}^{7} * A G E_{i t}+\varepsilon_{i t}^{7} \\
& Q R_{i t}=\alpha_{0}^{8}+\alpha_{1}^{8} * I N V T A_{i t}+\alpha_{2}^{8} * P R O F_{i t}+\alpha_{3}^{8} * D R_{i t}+\alpha_{4}^{8} * S I Z E_{i t}+\alpha_{5}^{8} * A G E_{i t}+\varepsilon_{i t}^{8}
\end{aligned}
$$




\section{The Empirical Results}

\subsection{The Descriptive Statistics}

Our sample is distributed into five sectors as follows (table2). The French sample is distributed as follows: 26 firms from the industrial sector, 14 firms from the service sector, 7 companies from the real estate sector. Most firms operate in the professional activities. However, for French market, our sample does not contain mining and agricultural firms. German firms are structured as follows: 70 industrial firms, 6 companies from the service sector and 8 firms from the real estate sector. For Italy, we have 31 industrial companies, 22 companies from the service sector, 11 companies from the real estate sector, two mining and agricultural firms and 18 firms from the professional, scientific and technical activities. In the three countries, firms are more concentrated in the industrial sector.

Table 2. Distribution of our sample into activity sectors

\begin{tabular}{|c|c|c|c|c|c|c|}
\hline & Manufacturing & $\begin{array}{c}\text { Trade and } \\
\text { Service }\end{array}$ & $\begin{array}{c}\text { Real } \\
\text { estate }\end{array}$ & $\begin{array}{c}\text { Mining and } \\
\text { agriculture }\end{array}$ & $\begin{array}{c}\text { Professional. scientific } \\
\text { and technical activities }\end{array}$ & Total \\
\hline French & 26 & 14 & 7 & 0 & 37 & 84 firms \\
\hline Germany & 70 & 6 & 8 & 0 & 0 & 84 firms \\
\hline Italy & 31 & 22 & 11 & 2 & 18 & 84 firms \\
\hline
\end{tabular}

Table 3 identifies the descriptive statistics. The results show that firms from French hold more cash with averages of 0.124 and 0.304 for cash and Quick ratios, respectively. Kim et al., (1998), Opler et al (1999), Foley et al (2007) and Mello et al (2008) found a mean value between 8 and 10,5\%. However, cash held by firms from Germany are more volatile. Similarly, investment measures ratios show that French firms over investment with growth rates of tangible fixed assets of $26.10 \%$ and $14.80 \%$ of total assets. German companies seem more profitable with an average value of 0.137 . However, the French firms have higher size and debt ratio with an average debt of 0,175. Jarrad, Sattar, and William (2008) find a leverage average value of 0,205. Moreover, French firms are older with an average age of 3,768 .

Table 3. Descriptive statistics

\begin{tabular}{|c|c|c|c|c|c|}
\hline & \multicolumn{4}{|c|}{ French } & \\
\hline & OBS & MEAN & STD DEV & MIN & MAX \\
\hline CASH & 664 & 0,124 & 0,105 & 0,0000216 & 0,987 \\
\hline QR & 629 & 0,304 & 0,198 & 0,0000456 & 0,977 \\
\hline INVTANG & 575 & 0,261 & 2,0180 & -1 & 41,359 \\
\hline INVTA & 580 & 0,148 & 0,532 & $-0,465$ & 7,760 \\
\hline PROF & 648 & 0,109 & 0,0615 & $-0,0904$ & 0,383 \\
\hline LEVERAG & 647 & 0,175 & 0,135 & 0,0000267 & 0,692 \\
\hline SIZE & 664 & 21,823 & 2,0238 & 16,458 & 26,206 \\
\hline \multirow[t]{3}{*}{ LOGAGE } & 669 & 3,768 & 0,833 & 0,693 & 5,176 \\
\hline & \multicolumn{4}{|c|}{ Germany } & \\
\hline & OBS & MEAN & STD DEV & MIN & MAX \\
\hline CASH & 613 & 0,100 & 0,108 & 0,000678 & 0,580 \\
\hline $\mathrm{QR}$ & 531 & 0,288 & 0,247 & 0,000906 & 0,997 \\
\hline
\end{tabular}




\begin{tabular}{|l|l|l|l|l|l|}
\hline INVTANG & 524 & 0,121 & 0,383 & -1 & 4,341 \\
\hline INVTA & 524 & 0,140 & 0,344 & $-0,998$ & 3,079 \\
\hline PROF & 576 & 0,137 & 0,104 & $-0,204$ & 0,798 \\
\hline LEVERAG & 603 & 0,153 & 0,120 & 0,0000102 & 0,790 \\
\hline SIZE & 613 & 20,997 & 2,0505 & 10,831 & 26,106 \\
\hline LOGAGE & 613 & 3,533 & 1,223 & 0,693 & 5,0814 \\
\hline \multicolumn{5}{|c|}{ Italy } \\
\hline & OBS & MEAN & STD DEV & MIN & MAX \\
\hline CASH & 593 & 0,0861 & 0,0776 & 0,0000107 & 0,556 \\
\hline QR & 570 & 0,230 & 0,204 & 0,0000573 & 0,987 \\
\hline INVTANG & 487 & 0,130 & 0,602 & $-0,999$ & 8,977 \\
\hline INVTA & 487 & 0,100 & 0,266 & $-0,999$ & 2,271 \\
\hline PROF & 581 & 0,109 & 0,098 & $-0,338$ & 0,403 \\
\hline LEVERAG & 560 & 0,169 & 0,120 & 0,0000014 & 0,573 \\
\hline SIZE & 594 & 21,0567 & 1,611 & 13,224 & 25,847 \\
\hline LOGAGE & 641 & 3,0583 & 0,966 & 0,693 & 4,976 \\
\hline
\end{tabular}

\subsection{Causality Relationship between Firm Investment and Cash Holdings}

The empirical results on causality relationship between firm investment and cash are presented in the table 4 .

Cash: the positive effect of cash on investment decision of the firm is checked for specification 3 for Germany. This result retains our second hypothesis. This positive effect means that new investment projects are funded by cash. Denis and Sibilkov (2010) suggest that a higher cash value stimulate new investment projects.

Firm investment: Unlike to the result of Ranjan, Krishnaswami and Larkin (2008), our empirical results stimulate that investment decision does not affect firm cash holdings. This result reject our first hypothesis.

Profitability: the positive impact of profitability on investment decision is recorded in specifications 3 and 4 for Germany. This result means that German firms use profits to invest. This interpretation rejects our hypothesis 3 a. However, we found a negative association between profitability and investment decision for specification 3 for French, and specification 2 for Italy. The negative impact of profitability on cash is checked only for specifications 5, 6 and 8 for French. We found a positive impact in specifications 5 and 6 for Germany. This positive effect is recorded for all specifications for Italy. This conclusion stimulates our hypothesis $3 \mathrm{~b}$. This result means that increase in earnings before interests and taxes increases the cash held by Italian firms (Bhattacharya and Nicodano, 2001)

Leverage: the empirical conclusions show a statistically significant negative impact of capital structure ratio on the investment decision for specifications 1 and 2 for Italy. This interpretation confirms our hypothesis $4 \mathrm{a}$. We can interpret this conclusion as follows. The increase in debt ratio means more cash. Managers, in this case, do not use this source of funding to invest in profitable projects. Furthermore, high levels of debt increase firms cash holdings to minimize bankruptcy risk. This result is observed for specifications 7 and 8 for all countries. This result is consistent with the findings of Bates et al (2009), Dittmar and 


\section{MInstitute ${ }_{\text {Int }}^{\text {Macrothink }}$}

Business and Economic Research

ISSN 2162-4860

2017, Vol. 7, No. 1

MahrtSmith (2007), Foley et al (2007), Harford et al (2008) and Opler et al (1999). However, the opposite effect was observed for the specification 5 and 6 for French and Italy. This interpretation confirms our hypothesis $4 \mathrm{~b}$.

Firm size: the empirical results show that large Germany companies invest more. This result means that for larger size firms, information asymmetry is low. In this case, these firms can obtain additional financing at the lowest cost. These funding sources will be manipulated to finance new investment projects. This result is valid specifications 1 and 3 for Germany. This result verifies our hypothesis 5a. Furthermore, like Nuno and Halit (2016), we obtained a negative and a statistically significant relationship for French for specification 2. The negative effect of firm size on cash is registered for all the specifications for Italy. This effect is recorded, also, for specifications 5 and 6 for French. This interpretation confirms our hypothesis $5 \mathrm{~b}$. We can manipulate this finding as follows. Larger firms transmit a good signal to external investors. Therefore, they can get additional funds at any time and at lower cost. Firms decrease their cash holdings. In fact, they will try to allocate excess cash to profitable investment projects. Otherwise, larger firms have the ability to accept external financing ( Lang et al., 1995; Rajan and Zingales, 1995). A positive effect of firm size on cash holdings is found in specifications 7 and 8 for Germany.

Firm Age: the empirical results show that older firms from French and Italy invest less. This result is observed for specifications 2, 3 and 4 for French and 3 and 4 for Italy. This finding does not rejects our hypothesis 6a. Moreover, the negative effect of firm age on cash is checked in all specifications for Germany. This finding rejects our hypothesis $6 \mathrm{~b}$. However, older firms from Italy ( specifications 6, 7 and 8) hold more cash. This result is checked in specifications 7 and 8 for French firms. This result confirms our hypothesis b.

Table 4. Causality relationship between firm investment and cash

\begin{tabular}{|c|c|c|c|c|c|c|c|c|}
\hline & & & & French & & & & \\
\hline & Spef 1 & Spef 2 & Spef 3 & Spef 4 & Spef 5 & Spef 6 & Spef 7 & Spef 8 \\
\hline & INVTANG & INVTANG & INVTA & INVTA & CASH & CASH & QR & QR \\
\hline $\mathrm{C}$ & $0,331^{*}$ & $0,570^{* * *}$ & 0,367 & 0,212 & $0,212^{* * *}$ & $0,233^{* * *}$ & $0,212^{* *}$ & $0,203^{*}$ \\
\hline $\mathrm{CASH}$ & 0,0793 & & $-0,0939$ & & & & & \\
\hline $\mathrm{QR}$ & & 0,122 & & $-0,128$ & & & & \\
\hline INVTANG & & & & & 0,00143 & & $-0,00199$ & \\
\hline INVTA & & & & & & $-0,00237$ & & $-0,0122$ \\
\hline PROF & $-0,0273$ & $-0,226$ & $-1,102^{* *}$ & $-0,554$ & $-0,0972^{* *}$ & $-0,102^{* * *}$ & $-0,149$ & $-0,173^{*}$ \\
\hline LEVERAG & 0,0910 & $-0,00687$ & 0,0422 & $-0,181$ & $-0,0491^{* * *}$ & $-0,0355^{* *}$ & $0,211^{* * *}$ & $0,209^{* * * *}$ \\
\hline SIZE & $-0,00866$ & $-0,0136^{*}$ & 0,00925 & 0,0147 & $-0,00394^{* *}$ & $-0,00474^{* * *}$ & $-0,00345$ & $-0,00260$ \\
\hline LOGAGE & $-0,0223$ & $-0,0483^{*}$ & $-0,0778^{*}$ & $-0,0700^{* *}$ & $-0,00210$ & $-0,00348$ & $-0,0262^{* *}$ & $0,0248^{*}$ \\
\hline OBS & 555 & 531 & 559 & 531 & 555 & 559 & 530 & 531 \\
\hline $\begin{array}{l}\text { R squared (\%) } \\
\text { Wald chi2 }\end{array}$ & 4,16 & 6,88 & 12,05 & 9,29 & 17,93 & 18,86 & 21,64 & 22,98 \\
\hline \multirow[t]{4}{*}{ Prob> F } & 0,5272 & 0,230 & 0,0341 & 0,0980 & 0,0030 & 0,0020 & 0,0006 & 0,0003 \\
\hline & & & & Germany & & & & \\
\hline & Spef 1 & Spef 2 & Spef 3 & Spef 4 & Spef 5 & Spef 6 & Spef 7 & Spef 8 \\
\hline & INVTANG & INVTANG & INVTA & INVTA & CASH & CASH & QR & QR \\
\hline $\mathrm{C}$ & $-3,570^{* * *}$ & $0,538^{* *}$ & $-0,0637$ & 0,00430 & $0,153^{* * *}$ & $0,155^{* * *}$ & 0,0823 & 0,0886 \\
\hline $\mathrm{CASH}$ & 0,442 & & $0,209^{* * * *}$ & & & & & \\
\hline $\mathrm{QR}$ & & 0,0379 & & 0,0194 & & & & \\
\hline
\end{tabular}




\begin{tabular}{|c|c|c|c|c|c|c|c|c|}
\hline INVTANG & & & & & 0,00680 & & 0,00640 & \\
\hline INVTA & & & & & & 0,00287 & & 0,00483 \\
\hline PROF & 0,273 & $-0,137$ & $0,375^{* * *}$ & $0,446^{* * *}$ & $0,0833^{* *}$ & $0,0846^{* *}$ & $-0,0982$ & $-0,100$ \\
\hline LEVERAG & 0,219 & 0,266 & $-0,0809$ & $-0,0316$ & $-0,00833$ & $-0,00550$ & $0,241^{* * *}$ & $0,229^{* * *}$ \\
\hline SIZE & $0,188^{* * *}$ & $-0,0182$ & $0,00557^{*}$ & 0,00123 & 0,000457 & 0,000306 & $0,0187^{* * *}$ & $0,0184^{* * *}$ \\
\hline LOGAGE & $-0,119$ & $-0,0242$ & $-0,00900$ & $-0,00372$ & $-0,0260^{* * *}$ & $-0,0257^{* * *}$ & $-0,0719^{* * *}$ & $-0,0711^{* * * *}$ \\
\hline OBS & 458 & 394 & 457 & 391 & 457 & 457 & 391 & 391 \\
\hline $\begin{array}{l}\text { R squared (\%) } \\
\text { Wald chi2 }\end{array}$ & 4,19 & 2,71 & 50,88 & 28,60 & 64,78 & 68,07 & 62,72 & 62,82 \\
\hline \multirow[t]{4}{*}{ Prob> F } & 0,0064 & 0,1280 & 0 & 0 & 0 & 0 & 0 & 0 \\
\hline & & & & Italy & & & & \\
\hline & Spef 1 & Spef 2 & Spef 3 & Spef 4 & Spef 5 & Spef 6 & Spef 7 & Spef 8 \\
\hline & INVTANG & INVTANG & INVTA & INVTA & CASH & CASH & QR & QR \\
\hline $\mathrm{C}$ & 0,0598 & $-0,876$ & 0,0851 & 0,141 & $0,147^{* * * *}$ & $0,153^{* * *}$ & $0,284^{* * *}$ & $0,269^{* * *}$ \\
\hline $\mathrm{CASH}$ & $-0,541$ & & 0,117 & & & & & \\
\hline QR & & 0,0224 & & $-0,0101$ & & & & \\
\hline INVTANG & & & & & $-0,00255$ & & $-0,00553$ & \\
\hline INVTA & & & & & & 0,00338 & & $-0,00974$ \\
\hline PROF & $-0,706$ & $-1,419^{* *}$ & $-0,00431$ & $-0,0445$ & $-0,0777^{* *}$ & $0,0829^{* * * *}$ & $0,399^{* * *}$ & $0,398^{* * *}$ \\
\hline LEVERAG & $-0,554^{*}$ & $-0,796^{*}$ & 0,0773 & 0,0441 & $-0,0395^{* *}$ & $-0,0401^{* *}$ & $0,235^{* * *}$ & $0,242^{* * *}$ \\
\hline SIZE & 0,0143 & 0,645 & 0,00412 & 0,00325 & $-0,00585^{* * *}$ & $-0,00618^{* * * *}$ & $-0,0156^{* * *}$ & $-0,0149^{* * * *}$ \\
\hline LOGAGE & $-0,00438$ & $-0,0214$ & $-0,0284^{*}$ & $-0,0332^{* *}$ & $0,0146^{* * *}$ & $0,0148^{* * *}$ & $0,0493^{* * *}$ & $0,0488^{* * *}$ \\
\hline OBS & 441 & 424 & 441 & 424 & 441 & 441 & 424 & 424 \\
\hline $\begin{array}{l}\text { R squared (\%) } \\
\text { Wald chi2 }\end{array}$ & 4,78 & 7,73 & 3,84 & 4,70 & 46,83 & 47,81 & 77,39 & 74,89 \\
\hline Prob> F & 0,4430 & 0,1715 & 0,5725 & 0,4533 & 0 & 0 & 0 & 0 \\
\hline
\end{tabular}

Note, ${ }^{* * *},{ }^{* * *}$ : significance at $10 \%, 5 \%$ and $1 \%$ levels respectively.

\section{Causality Relationship and the Effect of Activity Sectors}

Similarly to the works of Morck and Yeung (1991), Fama and French (1997), Opler, Pinkowitz, Stulz, and Williamson (1999) and Ranjan, Krishnaswami and Larkin (2008), we examine the importance of activity sectors in explaining the causality interdependence between firm investment and cash holdings. We consider five activity sectors: The service sector, the real estate sector, the professionals activities, manufacturing and mining and agriculture activities. The empirical results are manipulated in table 5 and 6 . We use as dependent variables, the growth rate of tangible fixed assets and cash ratio measured by liquidity and liquidity equivalents over total assets ratio. For French, the causality association between investment and cash is checked for the service sector. The results show that firm investment is an increasing function of cash. However, an increase in cash stimulate managers to invest more. This result can be highlighted by the fact that managers do not follow a retrenchment behaviour. A high profitability stimulates firms to invest for the service sector. The association between cash ratio and profitability is negative and statistically significant for the service, real estate and professional sectors. Larger firms from the real estate and professional sectors holds less of cash. Older firms invest less for manufacturing and service sectors. Furthermore, older firms belonging to service sector holds more cash. For Germany, causality between investment and cash is not statistically significant for all sectors. We found a positive association between firm investment and cash for the service sector. An increase in profitability stimulated an increased firm investment for the manufacturing sector. 
However, the hypothesis of a positive association of profitability and cash is checked for firms operating in the manufacturing and real estate sector. High debt levels lead to more investment for firms operating in the service sector. Like the French market, debt and cash are two substitutable funding sources for the service sector. Larger firms invest more and hold less cash for the real estate sector. However, larger firms invest less and hold more cash for the service sector. Older firms in the industrial, and service sectors hold less cash. However, the hypothesis of a negative association of firm age and firm investment is checked for firms operating in the manufacturing and real estate sectors. For Italy, causality interdependence between investment and cash is checked for the agriculture and mining sectors. Furthermore, we found a positive effect a positive effect of cash on firm investment for the real estate sector. However, we found a positive interdependence between profitability and cash for the manufacturing and service activities. A negative association is found for agriculture and mining and professional activities. We found a negative association between profitability and firm investment for the service sector. A positive association was found for agriculture and mining sector. An increase in debt ratio leads to a positive change in the tangible fixed assets growth rate for the agricultural and mining and professional sectors. A different conclusion is found for the manufacturing and real estate sectors. A negative association between debt ratio and cash is found for the manufacturing, real estate and agriculture and mining sectors. Indeed, larger size firms hold less cash for the service, agriculture and mining and professional sectors. Larger firms operating in professional activities invest more. A contradictory result is found for the agriculture and mining sector. In addition, older firms in the professional sector have less investment ratios, and hold more cash in the service and real estate sectors. However, older firms hold less cash for the manufacturing and agriculture and mining sectors, and invest more for the agriculture and mining sector.

Table 5. Effects of activity sectors in explaining causality relationship between firm investment and cash (French and Germany)

\begin{tabular}{|c|c|c|c|c|c|c|c|c|c|c|}
\hline \multicolumn{10}{|c|}{ France } \\
\hline & Spef 1 & Spef2 & Spef 3 & Spef 4 & Spef5 & Spef6 & Spef 7 & Spef 8 & Spef9 & Spef 10 \\
\hline & Manuf & Manuf & Service & Service & $\begin{array}{c}\text { Real } \\
\text { estate }\end{array}$ & $\begin{array}{c}\text { Real } \\
\text { estate }\end{array}$ & agricul & agricul & Professional & Professional \\
\hline & INTANG & CASH & INTANG & CASH & INTANG & CASH & INTANG & CASH & INTANG & CASH \\
\hline C & 1,00762 & $0,249^{* * *}$ & 0,256 & 0,0576 & 4,670 & $1,106^{* *}$ & & & $-0,341$ & $0,386^{* * *}$ \\
\hline CASH & $-0,896$ & & $22,242^{* * *}$ & & $-1,0140$ & & & & $-0,469$ & \\
\hline INVTANG & & $-0,00878$ & & $0,00826^{* * *}$ & & 0,00120 & & & $-0,00361$ \\
\hline PROF & $-0,630$ & 0,0255 & $31,334^{* * *}$ & $-0,271^{* * *}$ & $-3,157$ & $-0,486^{*}$ & & & $-0,389$ & $-0,136^{* * *}$ \\
\hline LEVERAG & $-0,778$ & $-0,158^{* * *}$ & $-7,944^{* * *}$ & 0,0284 & 0,249 & $-0,0847$ & & & $-0,128$ & 0,0190 \\
\hline SIZE & 0,0117 & $-0,00532$ & 0,459 & $-0,000835$ & $-0,102$ & $-0,0831^{* *}$ & & & 0,0236 & $-0,0128^{* * *}$ \\
\hline LOGAGE & $-0,204^{*}$ & $-0,00669$ & $-3,654^{* * *}$ & $0,0187^{*}$ & $-0,374$ & 0,218 & & & 0,00127 & 0,00766 \\
\hline OBS & 175 & 175 & 91 & 91 & 37 & 37 & & & 252 & 252 \\
\hline $\begin{array}{c}\text { R squared }(\%) \\
\text { Wald chi2 }\end{array}$ & 6,86 & 29,02 & 40,97 & 23,72 & 1,33 & 26,02 & & & 0,98 & 22,98 \\
\hline Prob> F & 0,2315 & 0 & 0 & 0,0002 & 0,9948 & 0,1421 & & & 0,7812 & 0,0003 \\
\hline & & & & Germany & & & & & & \\
\hline
\end{tabular}


$\underline{\text { Mll Macrothink }}$

Business and Economic Research ISSN 2162-4860

2017, Vol. 7, No. 1

\begin{tabular}{|c|c|c|c|c|c|c|c|c|c|c|}
\hline & Spef1 & Spef2 & Spef3 & Spef 4 & Spef5 & Spef6 & Spef 7 & Spef 8 & Spef9 & Spef 10 \\
\hline & Manuf & Manuf & Service & Service & $\begin{array}{l}\text { Real } \\
\text { estate }\end{array}$ & $\begin{array}{c}\text { Real } \\
\text { estate }\end{array}$ & agricul & agricul & Professional & Professional \\
\hline & INTANG & $\mathrm{CASH}$ & INTANG & $\mathrm{CASH}$ & INTANG & $\mathrm{CASH}$ & INTANG & $\mathrm{CASH}$ & INTANG & $\mathrm{CASH}$ \\
\hline $\mathrm{C}$ & 0,0558 & $0,160^{* * * *}$ & $11,200^{* *}$ & $-0,384$ & $-3,0864$ & $2,291^{* * *}$ & & & & \\
\hline $\mathrm{CASH}$ & $-0,0785$ & & 2,245 & & $-0,651$ & & & & & \\
\hline INVTANG & & $-0,0104$ & & $0,0299^{* * *}$ & & $-, 0,0462$ & & & & \\
\hline PROF & $0,377^{* * *}$ & $0,0914^{* *}$ & $-2,427$ & $-0,0575$ & 0,316 & $0,614^{* *}$ & & & & \\
\hline LEVERAG & $-0,0271$ & 0,0352 & $4,500^{* *}$ & $-0,923^{\text {**** }}$ & $-0,219$ & $-0,0400$ & & & & \\
\hline SIZE & 0,00220 & 0,0000707 & $-0,660^{* *}$ & $0,0646^{* *}$ & $0,331^{*}$ & $-0,107^{* *}$ & & & & \\
\hline LOGAGE & $-0,0222^{* * * *}$ & $-0,0273^{* * * *}$ & 0,565 & $-0,194^{* * * *}$ & $-1,00925^{* *}$ & 0,00347 & & & & \\
\hline OBS & 385 & 384 & 37 & 37 & 36 & 36 & & & & \\
\hline $\begin{array}{l}\text { R squared }(\%) \\
\text { Wald chi } 2\end{array}$ & 45,51 & 74,37 & 34,75 & 193,62 & 27,22 & 52,94 & & & & \\
\hline Prob $>$ F & 0 & 0 & 0,0055 & 0 & 0,1356 & 0,0013 & & & & \\
\hline
\end{tabular}

Note, ${ }^{* * *},{ }^{* * *}$ : significance at $10 \%, 5 \%$ and $1 \%$ levels respectively.

Table 6. Effects of activity sectors in explaining causality relationship between firm investment and cash (Italy)

\begin{tabular}{|l|l|l|l|l|l|l|l|l|l|l|}
\hline & Spef 1 & \multicolumn{1}{|c|}{ Spef2 } & Spef 3 & Spef 4 & Spef5 & Spef6 & Spef 7 & Spef 8 & Spef9 & Spef 10 \\
\hline & Manuf & Manuf & Service & Service & $\begin{array}{c}\text { Real } \\
\text { estate }\end{array}$ & $\begin{array}{c}\text { Real } \\
\text { estate }\end{array}$ & agricul & agricul & Professional & Professional \\
\hline & INTANG & CASH & INTANG & CASH & INTANG & CASH & INTANG & CASH & INTANG & CASH \\
\hline C & $-0,0338$ & 0,0544 & 0,859 & $0,126^{* *}$ & 1,752 & 0,130 & $2,743^{* *}$ & $1,722^{* * *}$ & $-2,438^{* *}$ & $0,313^{* * *}$ \\
\hline CASH & $-0,899$ & & $-0,318$ & & $-5,729^{*}$ & & $1,130^{* * *}$ & & $-0,622$ & \\
\hline INVTANG & & $-0,0141^{* *}$ & & 0,00114 & & $-0,00173$ & & $0,591^{* * *}$ & & 0,0139 \\
\hline PROF & $-0,754$ & $0,0873^{*}$ & $-4,156^{* *}$ & $0,156^{* * *}$ & 1,391 & 0,196 & $3,359^{* * *}$ & $-1,806^{* * *}$ & 0,440 & $-0,139^{* * *}$ \\
\hline LEVERAG & $-1,271^{* * *}$ & $-0,161^{* * *}$ & 0,548 & $-0,0138$ & $-3,182^{*}$ & $-0,138^{* * *}$ & $1,916^{* * *}$ & $-1,00783^{* * *}$ & $1,377^{* *}$ & $-0,0318$ \\
\hline SIZE & 0,0347 & 0,00443 & 0,00381 & $-0,00747^{* * *}$ & $-0,0902$ & $-0,00809$ & $-0,255^{* * *}$ & $-0,0385^{* * *}$ & $0,140^{* * *}$ & $-0,00112^{* * *}$ \\
\hline LOGAGE & $-0,0596$ & $-0,0151^{* *}$ & $-0,116$ & $0,0270^{* * *}$ & $0,421^{*}$ & $0,0411^{* * *}$ & $0,669^{* * *}$ & $-0,0909^{* *}$ & $-0,294^{* *}$ & 0,00728 \\
\hline OBS & 171 & 171 & 104 & 105 & 64 & 64 & 11 & 11 & 92 & 92 \\
\hline $\begin{array}{l}\text { R squared }(\%) \\
\text { Wald chi2 }\end{array}$ & 11,04 & 27,02 & 6,81 & 347,06 & 5,10 & 40,33 & 99,57 & 1017,83 & 19,85 & 31,50 \\
\hline Prob> F & 0,0506 & 0,0001 & 0,2350 & 0 & 0,4043 & 0 & 0,0001 & 0 & 0,0081 & 0 \\
\hline
\end{tabular}

Note, ${ }^{* * *},{ }^{* * *}$ : significance at $10 \%, 5 \%$ and $1 \%$ levels respectively.

\section{Conclusion}

Greenwald et al. (1984) note that in an imperfect market, cash holdings determines firm investment value. Fazzari et al., (1988), Devereux and Schiantarelli (1990), Hoshi et al (1991), Schaller (1993), and Gilchrist and Himmelberg (1995) have examined the effect of internal and external financing on corporate investment. Kaplan and Zingales (1997) argue that availability of internal funds can explain firm investment. Palani, Kumar, Leigh (1998) tests the relationship between cash flows availability and firm investment. Our empirical results reject the existence of a causality association between firm investment and cash holdings. Our results interpret a positive association between our dependant variables for 


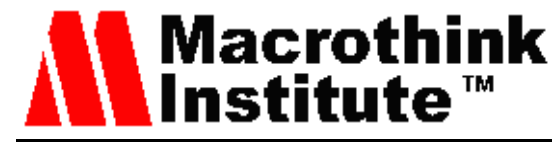

Business and Economic Research ISSN 2162-4860 2017, Vol. 7, No. 1

Germany. Therefore, we can suggest that cash holdings can stimulate managers to manipulate more investment projects. Furthermore, more profitable investment projects can increase cash holding for Italy. We have examined the effect of activity sectors on the causality relationship between firm investment and cash. Causality is checked for the service sector for French firms, and the agriculture and mining sectors for Italy. However, this interdependence is not statistically significant for German firms. The results of our control variables are as follows: a negative effect of profitability on total assets growth for Italian firms. However, more profitability increases cash holdings for manufacturing and real estate firms in Germany, and manufacturing and service firms in Italy. Overall, debt ratio negatively affects investment decision and cash for all firms, except service sector in Germany and agriculture and mining and professional activities in Italy (John, 1993; Kim et al. ,1998). Large size firm invest more for the real estate sector in Germany, and professional activities in Italy, and hold less cash for real estate and professional activities in French, and the real estate sector for Germany, and the service, agriculture and mining and professional sectors for Italy. Finally, we found differences in firm age effect on firm investment and cash holdings.

\section{References}

Abadie, A., \& Imbens, G. W. (2006). Large sample properties of matching estimators for average treatment effects. Econometrica, 74, 235-267.

https://doi.org/10.1111/j.1468-0262.2006.00655.x

Acharya, V., Almeida, H., \& Campello, M. (2013). Aggregate risk and the choice between cash and lines of credit. Journal of Finance, 68, 2059-2116.

https://doi.org/10.1111/jofi.12056

Acharya, V., Almeida, H., \& Campello, M. (2007). Is cash negative debt? A hedging perspective on corporate financial policies. Journal of Financial Intermediation, 16, 515-554. https://doi.org/10.1016/j.jfi.2007.04.001

Aldrich, H., \& Auster, E. R. (1986). Even dwarfs started small: liabilities of age and size and their strategic implications. Research in Organizational Behavior, 8, 165-198.

Almeida, H., Campello, M., \& Weisbach, M. S. (2004). The cash flow sensitivity of cash. Journal of Finance, 59, 1777-1804. https://doi.org/10.1111/j.1540-6261.2004.00679.x

Andres, C. (2011). Family ownership, financing constraints and investment decisions. Applied Financial Economics, 22, 1641-1659.

https://doi.org/10.1080/09603107.2011.589805

Bates, T. W., Kahle, K. M., \& Stulz, R. M. (2009). Why do U.S. firms hold so much more cash than they used to? Journal of Finance, 44, 1985-2021.

https://doi.org/10.1111/j.1540-6261.2009.01492.x

Bhattacharya, S., \& Nicodano, G. (2001). Insider trading, investment, and liquidity: a welfare analysis. Journal of Finance, 56(3), 1141-1156. https://doi.org/10.1111/0022-1082.00359

Brown, James, R., \& Petersen, Bruce, C. (2011). Cash holdings and R\&D smoothing. J. Corp 
Finance, 17(3), 694-709. https://doi.org/10.1016/j.jcorpfin.2010.01.003

Caballero, R. (1990). Consumption puzzles and precautionary savings. Journal of Monetary Economics, 25, 113-136. https://doi.org/10.1016/0304-3932(90)90048-9

Çolak, G., \& Whited, T. M. (2007). Spin-offs, divestitures, and conglomerate investment. Review of Financial Studies, 20, 557-595. https://doi.org/10.1093/rfs/hh1022

Dany, Aoun, \& Junseok, Hwang (2008). The effects of cash flow and size on the investment decisions of ICT firms: A dynamic approach, Information Economics and Policy, 20, 120-134. https://doi.org/10.1016/j.infoecopol.2007.12.001

Denis, David J., \& Sibilkov, Valeriy. (2010). Financial constraints, investment, and the value of cash holdings. Review of Financial Studies, 23(1), 247-269.

https://doi.org/10.1093/rfs/hhp031

Devereux, M., \& Schiantarelli, F. (1990). Investment, fnancial factors, and cash ${ }^{-}$fow: evidence from UK panel data. In: Hubbard, R.G. (Ed.), Asymmetric Information, Corporate Finance, and Investment, University of Chicago Press and NBER, Chicago, 279-306.

Dittmar, A., \& Mahrt-Smith, J., (2007). Corporate governance and the value of cash holdings. Journal of Financial Economics, 83, 599-634. https://doi.org/10.1016/j.jfineco.2005.12.006

Dittmar, A., Mahrt-Smith, J., \& Servaes, H. (2003). International corporate governance and corporate cash holdings. Journal of Financial and Quantitative Analysis, 38, 111-133. https://doi.org/10.2307/4126766

Dreze, J., \& Modigliani, F., (1972). Consumption decisions under uncertainty. Journal of Economic Theory, 5, 308-335. https://doi.org/10.1016/0022-0531(72)90044-0

Duchin, R. (2010). Cash holdings and corporate diversification. Journal of Finance, 65, 955-992. https://doi.org/10.1111/j.1540-6261.2010.01558.x

Duchin, Ran, Ozbas, Oguzhan, \& Sensoy, Berk, A. (2010). Costly external finance, corporate investment, and the subprime mortgage credit crisis. Journal of Financial Economics, 97, 420-435. https://doi.org/10.1016/j.jfineco.2009.12.008

Eric, R. Brisker, Gönül, Çolak, \& David, R. Peterson. (2013). Changes in cash holdings around the S\&P 500 additions, Journal of Banking \& Finance, 37, 1787-1807.

https://doi.org/10.1016/j.jbankfin.2013.01.021

Fama, E., \& French, K., (1997). Industry costs of equity. Journal of Financial Economics, 43, 153-193. https://doi.org/10.1016/S0304-405X(96)00896-3

Fazzari, S. M., Hubbard, R. G., \& Petersen, B. (1988). Financing constraints and corporate investment. Brooking Papers on Economic Activity, 141-195.

Fazzari, S., \& Petersen, B. (1993). Working capital and fixed investments: new evidence on financing constraints. Rand Journal of Economics, 23, 328-342.

https://doi.org/10.2307/2555961 
Foley, C. F., Hartzell, J., Titman, S., \& Twite, G. (2007). Why do firms hold so much cash? A tax-based explanation. Journal of Financial Economics, 86, 579-607.

https://doi.org/10.1016/j.jfineco.2006.11.006

Gilchrist, S., \& Himmelberg, C. P. (1995). Evidence on the role of cash flow for investment. Journal of Monetary Economics, 36, 541-572.

Goergen, M., \& Renneboog, L. (2001). Investment policy, internal financing and ownership concentration in the UK. Journal of Corporate Finance, 7, 257-284.

https://doi.org/10.1016/S0929-1199(01)00022-0

Greenwald, B., Stiglitz, J. E., \& Weiss, A. (1984). Information imperfections in the capital market and macroeconomic fluctuations. American Economic Review, 74, 194-199.

Harford, J., Klasa, S., \& Maxwell, W. F. (2014). Refinancing risk and cash holdings. Journal of Finance, 69, 975-1012. https://doi.org/10.1111/jofi.12133

Harford, J. (1999). Corporate cash reserves and acquisitions. Journal of Finance, 54, 1969-1997. https://doi.org/10.1111/0022-1082.00179

Harford, J., Mansi, S. A., \& Maxwell, W. F. (2008). Corporate governance and firm cash holdings in the US. Journal of Financial Economics, 87, 535-555.

https://doi.org/10.1016/j.jfineco.2007.04.002

Hoshi, T., Kashyap, A., \& Scharfstein, D. (1991).Corporate structure liquidity and investment: Evidence from Japanese industrial groups. Quarterly Journal of Economics, 106, 33-60. https://doi.org/10.2307/2937905

Hovakimian, G., \& Titman, S. (2003). Corporate investment with financial constraints: Sensitivity of investment to funds from voluntary asset sales. NBER working paper no: 9432.

Jarrad, Harforda, Sattar, A. Mansib., \& William, F. Maxwellc. (2008). Corporate governance and firm cash holdings in the US, Journal of Financial Economics, 87, 535-555.

https://doi.org/10.1016/j.jfineco.2007.04.002

John, T. A. (1993). Accounting measures of corporate liquidity, leverage, and costs of financial distress. Financial Management, 22, 91-100. https://doi.org/10.2307/3665930

J. Thomas Connelly. (2016). Investment policy at family firms: Evidence from Thailand. Journal of Economics and Business, 83, 91-122.

https://doi.org/10.1016/j.jeconbus.2015.08.003

Kaplan, S. N., \& Zingales, L. (1997). Do investment-cash flow sensitivities provide useful measures of financing constraints? Quarterly Journal of Economics, 112, 169-215. https://doi.org/10.1162/003355397555163

Kim, C., Mauer, D., \& Sherman, A. (1998). The determinants of corporate liquidity: theory and evidence. Journal of Financial and Quantitative Analysis, 33, 335-359.

https://doi.org/10.2307/2331099 


\section{Macrothink}

Business and Economic Research ISSN 2162-4860 2017, Vol. 7, No. 1

Lang, L., Poulsen, A., \& Stulz, R. (1995). Asset sales, firm performance, and the agency costs of managerial discretion. Journal of Financial Economics, 37, 3-37.

https://doi.org/10.1016/0304-405X(94)00791-X

Leland, H. (1968). Saving and uncertainty: the precautionary demand for saving. Quarterly Journal of Economics, 82, 465-473. https://doi.org/10.2307/1879518

Mello, R., Krishnaswami, S., \& Larkin, P. J. (2008). Determinants of corporate cash holdings: evidence from spin-offs. Journal of Banking and Finance, 32, 1209-1220.

https://doi.org/10.1016/j.jbankfin.2007.10.005

Mikkelson, W., \& Partch, M. (2003). Do persistent large cash reserves hinder performance? Journal of Financial and Quantitative Analysis, 38, 275-294.

https://doi.org/10.2307/4126751

Minton, B., \& Schrand, C. (1999). The impact of cash flow volatility on discretionary investment and the cost of debt and equity financing. Journal of Financial Economics, 54, 423-460. https://doi.org/10.1016/S0304-405X(99)00042-2

Morck, R., \& Yeung, B. (1991). Why investors value multinationality. Journal of Business, 64, 165-187. https://doi.org/10.1086/296532

Myers, S., \& Majluf, N. (1984). Corporate financing and investment decisions when firms have information investors do not have. Journal of Financial Economics, 13, 187-221. https://doi.org/10.1016/0304-405X(84)90023-0

Nuno Fernandes, \& Halit, Gonenc. (2016). Multinationals and cash holdings, Journal of Corporate Finance, 39, 139-154. https://doi.org/10.1016/j.jcorpfin.2016.06.003

Opler, T., Pinkowitz, L., Stulz, R., \& Williamson, R. (1999). The determinants and implications of corporate cash holdings. Journal of Financial Economics, 52, 3-46.

https://doi.org/10.1016/S0304-405X(99)00003-3

Palani-Rajan Kadapakkam, P. C. Kumar, \& Leigh A. Riddick. (1998). The impact of cash flows and firm size on investment: The international evidence, Journal of Banking \& Finance, 22, 293-320. https://doi.org/10.1016/S0378-4266(97)00059-9

Rajan, R. G., \& Zingales, L. (1995). What do we know about capital structure? Some evidence from international data. Journal of Finance, 50, 1421-1460. https://doi.org/10.1111/j.1540-6261.1995.tb05184.x

Ranjan, D’Mello, Sudha, Krishnaswami, \& Patrick, J. Larkin. (2008). Determinants of corporate cash holdings: Evidence from spin-offs, Journal of Banking \& Finance, 32, 1209-1220. https://doi.org/10.1016/j.jbankfin.2007.10.005

Schaller, H. (1993). Asymmetric information, liquidity constraints, and Canadian investment. Canadian Journal of Economics, 36(3), 552-574.

Seungjin, Han, \& Jiaping, Qiu. (2007). Corporate precautionary cash holdings, Journal of Corporate Finance, 13, 43-57. https://doi.org/10.1016/j.jcorpfin.2006.05.002 


\section{Macrothink}

Stuart, T. E. (2000). Interorganizational alliances and the performance of firms: a study of growth and innovation rates in a high-technology industry. Strategic Management Journal, 21, 791-811. https://doi.org/10.1002/1097-0266(200008)21:8<791::AID-SMJ121>3.0.CO;2-K

Titman, S., \& Wessels, R. (1988). The determinants of capital structure choice. Journal of Finance, 43, 1-19. https://doi.org/10.1111/j.1540-6261.1988.tb02585.x

Wei, K. C. J., \& Zhang, Y. (2008). Ownership structure, cash flow, and capital investment: Evidence from East Asian economies before the financial crisis. Journal of Corporate Finance, 14, 118-132. https://doi.org/10.1016/j.jcorpfin.2008.02.002

Whited, T. (1992). Debt, liquidity constraints, and corporate investment: evidence from panel data. Journal of Finance, 47, 1425-1460. https://doi.org/10.1111/j.1540-6261.1992.tb04664.x

William, Mingyan, Cheung, Richard, Chung, \& Scott, Fung. (2015). The effects of stock liquidity on firm value and corporate governance: Endogeneity and the REIT experiment, Journal of Corporate Finance, 35, 211-231. https://doi.org/10.1016/j.jcorpfin.2015.09.001

\section{Copyright Disclaimer}

Copyright for this article is retained by the author(s), with first publication rights granted to the journal.

This is an open-access article distributed under the terms and conditions of the Creative Commons Attribution license (http://creativecommons.org/licenses/by/3.0/). 